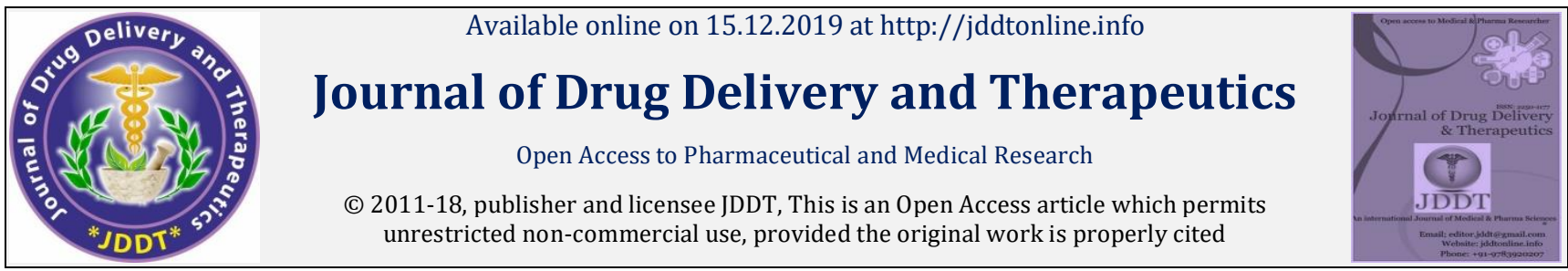

Open 2 Access

Review Article

\title{
Microsponges: A Novel Strategy to Control the Delivery Rate of Active Agents with Reduced Skin Irritancy
}

\author{
Vishwakarma Pramila* Choudhary Ramraj \\ Chameli Devi Institute of Pharmacy Indore M.P., India
}

\begin{abstract}
Microsponges are particulate system which is composed by porous polymeric material. As compare to Conventional topical formulations, microsponge provide controlled release of the drug in the epidermis, it is to ensure that the drug is mainly localized and does not unduly entering the systemic circulation, it is a new area of research. The active ingredient needs to maximize the time to stay on the skin, while reducing transdermal penetration. Apart from this, there is a problem of unethical vehicles that can be viscous sticky deformation and skin irritation. One of the biggest challenges of now a days is to control irritability for a predetermined site of active agents in the human body. Microsponges delivery system is a unique technique for controlled release with low irritant involving many triggers of Mechanism for the release of drugs. The Microsponge Delivery system is a polymeric porous microspheres, which can trap a wide range of effective elements such as anti-fungus, anti-infected, anti- inflammatory agent, fragrance and essential agent. This review includes different techniques used to prepare microsponges, formulation consideration, safety consideration, drug release mechanism, and challenges with microsponge drug delivery system along with their advantages, disadvantages and applications. In the current review, we summarize the updated application and capacity of Microsponge as an effective drug-delivery system to reduce skin irritation.
\end{abstract}

Keywords: Microsponges; quasi-emulsion solvent diffusion; Porous microspheres; Controlled release.

Article Info: Received 08 Oct 2019; Review Completed 22 Nov 2019; Accepted 29 Nov 2019; Available online 15 Dec 2019

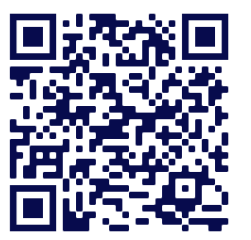

\section{Cite this article as:}

Vishwakarma P, Choudhary R, Microsponges: A Novel Strategy to Control the Delivery Rate of Active Agents with Reduced Skin Irritancy, Journal of Drug Delivery and Therapeutics. 2019; 9(6-s):238-247 http://dx.doi.org/10.22270/jddt.v9i6s. 3757

Vishwakarma Pramila, Chameli Devi Institute of Pharmacy Indore M.P., India

\section{INTRODUCTION}

All conventional topical formulations are work on the outer layers of the skin. When the active ingredients of these formulations are released after application, an extremely concentrated layer of active ingredient is fashioned, that is speedily absorbed. Thus, there is a rightful require for drug delivery systems to prolong the time so that active ingredients can be retained on the surface of the skin or abandoning transdermal penetration within epidermis. In addition, as a result of high concentration of active agents in traditional topical dosage forms, many side effects are recorded such as irritation and allergic reactions [1]. The additional potential limitation of topical conventional formulations is uncontrolled evaporation of the active ingredient, unethical vehicles that are sleek, sticky and discoloration, and drugs may be cause the discrepancy with vehicles. This reduces the compliance of patients' treatment [2]. One of the biggest challenges for pharmaceutical science is to control the distribution rate of active ingredients in a human body on a predetermined site, to control the release of the drug in epidermis, ensuring that the drug is mostly localized and does not enter unnecessarily in systemic circulation, [3]. The scenario of drug delivery technology has become very enthusiastic and is developing rapidly. The greater development in the delivery system is being integrated to optimize the effectiveness and cost effectiveness of the medicine [4]. In the last few years, there has been a significant growth in the number of products based on the new drug delivery system, for improving safety, efficacy and patient compliance has been achieved by incorporating an existing drug into a new drug delivery system [5].

Carrier technologies are a possible solution to these challenges. Microparticles and nanoparticles have been researched rapidly for targeted and continuous elease of drugs. It includes microspheres, liposomes, and nanopactics, which modify the absorption and release characteristics of drugs. Microspheres are unable to control the drug's release rate manually. Once the outer wall is broken, the drug contained in Microspheres will exit from it [6]. In liposomes, fluttering of lesser drugs, difficulty in preparing deformities, limited chemical stability and microbial stability worsens, hence the need of the preservatives. In solid lipid nanoparticles, there are more benefits in topical drug delivery. Nanomaterial can easily enter systemic circulation by inhalation or injection, and probably through skin 
absorption, especially if the skin is damaged [7]. Only once in the bloodstream, nanomaterials can be taken almost in the body and taken by the limbs and tissues including the brain, heart, liver, kidney, spleen, bone marrow and nervous system. Micro-sponge-based polymeric microsphere helps overcome problems related to superior technologies. Compared to conventional method, the microscope system can stop epidermis and excessive accumulation of material within the skin [8]. Furthermore, the MDS can reduce the irritation of skin irritating drug without reducing the effectiveness of the system. For example, MDS-benzoyl peroxide formulations have a minimal irritation by gradually delivering the active ingredient to the skin [9].

\section{MICROSPONGES DELIVERY SYSTEM (MDS)}

\subsection{Overview of microsponges}

Microsponges Delivery System (MDS) is porous, crosslinked, polymeric microspheres, polymeric systems, which include porous microsphere, which can entangle a wide range of drug and then release them into skin at one time and in response to trigger". Microsponges technology was developed In 1987, Won pioneered microsponge system (MDS) technology, These patents include Advanced Polymer Systems, Inc. (United States) [10]. Microsponges are small sponges, like circular particles, in which there is no processed structure with a large cough surface through which the active ingredient is released in a controlled manner. The size of the microscope ranges from $5-300 \mu \mathrm{m}$ in diameter and in a specific $25 \mu \mathrm{m}$ area, the spacing of up to 250000 pores and an internal pore structure can be equal to 10 feet length, making it almost $1 \mathrm{ml}$ / gram for all embracing drug retention. The surface can be separated from 0.1 to 0.3 centimeters / grams in quantity of 20 to $500 \mathrm{~m} / \mathrm{g}$ and 2 pore [11].

The Scanning electron microscopy of microsponge particles shows that its internal structure is "bag of marbles". It is a unique technique for controlling release of topicall agents, in which microporous pearls are normally 10-25 microns in diameter, loaded with active ingredients, which in turn result in them in a controlled manner into the skin at a time, including triggers rubbing, $\mathrm{pH}$, friction moisture and ambient skin temperature [9]. When it is applied to the skin, drug release can be controlled through spread. This controlled release of active ingredient on the skin at the time has been done to provide enhanced product efficacy, tolerance, benignity benefits, and to reduce the irritability associated with powerful therapeutic agents such as retinoid or benzyl peroxide and the range of a comprehensive skin therapies [12].
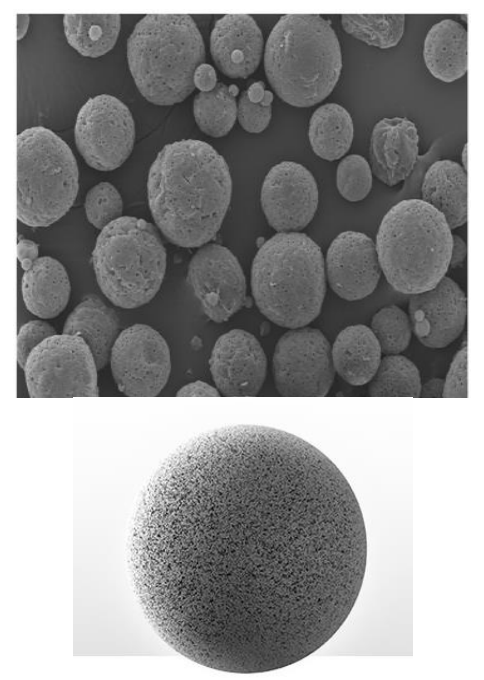

Fig 1: Structure of Microsponge
Microsponges have the ability to absorb or load high volume of active ingredients on the particle or its surface. Microsponges separate from other types of dermatology delivery systems, the ability to be active to activate its intensity up to 3 times. In the distinction, Micro-sponge technology allows a flat and constant rate of release, which reduces irritation in maintaining efficacy. Microsponges are able to absorb the secretion of the skin, so the skin glows down and shines from the skin [12]. MDS can prevent accumulation of ingredients within the skin. Potentially, they can reduce the irritation of skin irritating drugs, without reducing their efficacy [13]. Another advantage is the potential bacterial contamination of the material entrapped in the microsponge since the size of the pore diameter is lighter, the bacteria from 0.007 to 0.2 microns cannot penetrate into the digging structure of the microsponges[12]. Due to the trapping of drug molecules within the microscopic holes, the rate of solubilization of poorly water-soluble drug becomes improved. When the drug molecules are trapped in the pores, then the particle size is shortened due to the small aperture size $(\sim 0.07-0.25$ $\mu \mathrm{m})$. As the particle size decreases, its surface area increases, which leads to increased drug solubility [14].

Micro-sponge drug delivery technology is far and wide for dermatology drug delivery products. But Micro-sponges drug delivery also extends its application in oral drug delivery, bone and tissue engineering in the investigation of illness and RNAi silencing [15].

Recent applications from Microsponges obtained from seaweed can help in the diagnosis of cardiovascular disease, cancer, HIV and other diseases, and a lot less cost than current diagnostic methods. Biomarkers are hidden in small sponges set in an array of pyramid-shaped funnels in the heart of the PBNC microprocessor, which is in the shape of a credit card [16].

Nowadays, many Food and Drug Administration (FDA) approved products such as Retin-A Micro® $(0.1$ or $0.04 \%$ tretinoin) and Carac (0.5\% 5- flurouracil) are used for acne treatment and actinic keratos [17].

\subsection{Potential feature of Microsponges drug delivery system $[18,19]$.}

- $\quad$ MDS are unbreakable on the range of pH 1-11.

- $\quad$ They are mostly affiliates with vehicles and excipients.

- Microsponges have increased the efficiency of trapping by 50 to $60 \%$.

- They flow freely and are cost effective and have more sense of flexibility.

- Due to self-sterility, their average pore size is around 0.25 microns, while bacteria cannot Infiltration in the pores.

- These particles are deployed in the shape of the skin absorbing.

- $\quad$ Microsponges are microscopic spheres able to absorb skin secretion, therefore, to reduce oiliness and shine with skin.

- Microsponges formulation can absorb 6 times the weight of oil without drying.

- It provides 12 hours of continuous action, i.e. extended release.

- Microsponges are non-allergic, non-irritating, nonmetagenic and non-toxic. 
Microsponges particles themselves are very large, so they are complex to absorb in the skin and this protects these Microsponges materials by avoiding the side effects microsponges adjutants. Microsponges formulations can also be cost effective for the use of cosmetic mass market where the cost of materials is important [20]. Inequalities for other technologies like microencapsulation and liposomes, chemical stability in MDS, a wide range of high payloads and easy to prepare [21].

\subsection{Advantages of microsponge delivery systems [16, 22, and 23].}

Table 1: Advantages of microsponge delivery systems

\begin{tabular}{|l|l|l|}
\hline S.No & Advantages & Comments \\
\hline 1. & High Surface Area & $\begin{array}{l}\text { The total pore length of approximately 10 feet in 25 } \mu \text { sphere can be around 1 mg / gram } \\
\text { with the amount of quantity and can have up to 25,000 pore. It provides a broad surface } \\
\text { area to trap high. }\end{array}$ \\
\hline 2. & Range & $\begin{array}{l}\text { Microsponges can be prepared to regulate their properties and make them suitable for an } \\
\text { accurate purpose. Various parameters can be converted into which particle size, pore } \\
\text { characteristics and hardness are included. }\end{array}$ \\
\hline 3. & $\begin{array}{l}\text { Simple Production } \\
\text { Methodology }\end{array}$ & $\begin{array}{l}\text { Production of such Microsponges is comparatively simple in scaling up and therefore has } \\
\text { an advanced capacity for commercialization. }\end{array}$ \\
\hline 5. & Programmable Release & $\begin{array}{l}\text { Pressure Triggered Systems } \\
\text { Temperature Triggered Systems } \\
\text { pH Triggered Systems } \\
\text { Solubility Triggered Systems }\end{array}$ \\
\hline
\end{tabular}

Table 2: - Advantages of Microsponges over Other Formulations

\begin{tabular}{|l|l|l|l|}
\hline S.No & Advantages & Other Formulations & Microsponges formulation \\
\hline 1. & $\begin{array}{l}\text { Advantages over } \\
\text { Conventional } \\
\text { Formulations }\end{array}$ & $\begin{array}{l}\text { Conventional formulation actively produce a } \\
\text { highly concentrated layer of active ingredient, } \\
\text { which are rapidly absorbed. }\end{array}$ & $\begin{array}{l}\text { MDS can prevent excessive accumulation } \\
\text { of drugs within the skin. Potentially, the } \\
\text { MDS can reduce the irritation of skin } \\
\text { irritating active ingredient without } \\
\text { significantly reducing their efficacy [9]s. }\end{array}$ \\
\hline 2. & $\begin{array}{l}\text { Advantages over } \\
\text { Microencapsulation } \\
\text { and Liposomes }\end{array}$ & $\begin{array}{l}\text { Microcapsules cannot do more often than } \\
\text { controlling the release rate of activation. Once the } \\
\text { wall is broken the activations contained within the } \\
\text { microcapsules will be unconstrained. }\end{array}$ & $\begin{array}{l}\text { In the inequality for Microencapsulation } \\
\text { and Liposomes system, the } \\
\text { Microsponges system prevents these } \\
\text { limitations [9, 24]. }\end{array}$ \\
\hline 3. & $\begin{array}{l}\text { Advantages over } \\
\text { Ointments }\end{array}$ & $\begin{array}{l}\text { Ointments are often invisible, sleek and sticky } \\
\text { from aesthetics, which often occur in lack of } \\
\text { patient adherence. These vehicles require high } \\
\text { concentrations of active agents for effective } \\
\text { treatment because their delivery system has less } \\
\text { efficiency, causing significant users to have } \\
\text { irritation and allergic reactions. }\end{array}$ & $\begin{array}{l}\text { The microscope system increases the } \\
\text { maximum amount of time, which is an } \\
\text { active ingredient on the skin surface or } \\
\text { in epidermis, while reducing its } \\
\text { transdermal penetration in the body [12, } \\
\text { 25]. }\end{array}$ \\
\hline
\end{tabular}

\subsection{Category of drugs Explored in microsponges delivery system [26].}

- Anti-Inflammatory

- Anti Fungals

- Anti-Acne

- Anti-Dandruffs

- $\quad$ Skin Depigmenting Agnts

- Sunscreens
- Antipruritics

- Rubefacients

\subsection{Drug release mechanism of microsponges}

Microsponges contain a large amount of porous microspheres, which have a complex network of interconnection with a non-compressed structure. The active ingredient is added to the trapped form in the vehicle. Once formulation is applied to the preferred area of the skin, the active ingredient spreads out of the spheres into vehicles and then on the skin, reduces the vehicle, which becomes 
unsaturated, therefore, disturb the equilibrium. It will start the flow of particle from the micro-sponge into the vehicle, and from it to the skin, until the vehicle is dry or absorbed [12]. Even then, microsponge particles retaining to the surface of the stratum cornem will continue to activate the skin gradually, which will release over time for a long time. This proposed mechanism of action demonstrates the importance of building vehicles to trap micro-sponges. If the active product is very soluble in their favorite vehicle during preparation, then the products will not get the desired benefits of release [12]. As a replacement, they will behave as active microsponge may intend to release active elements in quantity over time, in response to one or more of the following external triggers added in the vehicle in an open form. Pressure, temperature change and solubility etc [4].

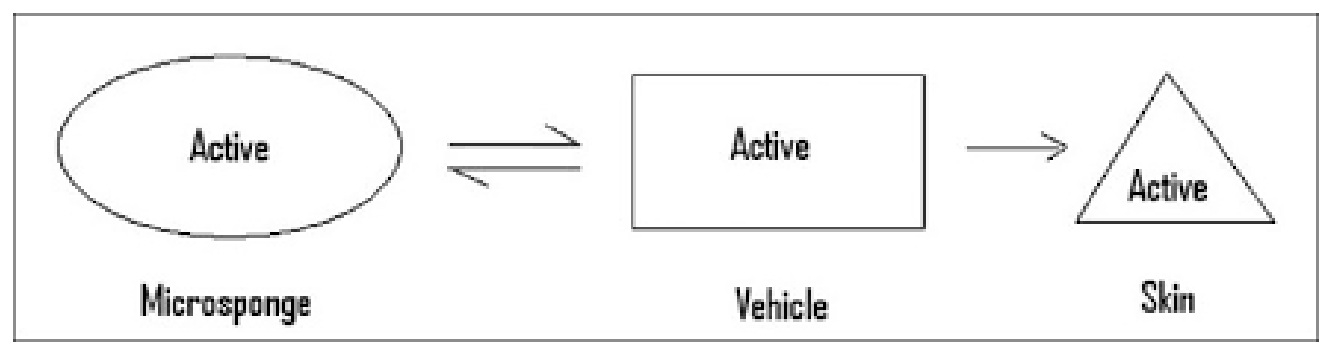

Fig: 2 Drug release from microsponge

\subsubsection{Release triggers [14].}

The release trigger is defined as a mechanism, which can be used to release or accelerate active agents from MDS. These mechanisms are given below:

Table 3: Drug release mechanism of microsponge

\begin{tabular}{|l|l|l|}
\hline S.No & Release triggers & Drug release mechanism \\
\hline 1. & Pressure triggered systems & $\begin{array}{l}\text { Rubbing or pressure is applied to the active ingredient can release from the } \\
\text { microsponges into the skin. }\end{array}$ \\
\hline 2. & pH triggered systems & $\begin{array}{l}\text { The coating on microsponges can be modified by triggering the pH-based } \\
\text { release of activation. }\end{array}$ \\
\hline 3. & Temperature change triggered systems & $\begin{array}{l}\text { At room temperature, some trapped active ingredients can be viscous to the } \\
\text { sudden flow of the skin from the microsponges. }\end{array}$ \\
\hline 4. & Solubility triggered systems & $\begin{array}{l}\text { Microsponges loaded with water-sweeping materials such as antiseptics and } \\
\text { antipersprinters will issue components in the presence of Warter. }\end{array}$ \\
\hline
\end{tabular}

\subsection{Formulation considerations}

Action taken in microsponges drug distribution system can then be included in many products like as lotions, creams, soaps and powders. While preparing the vehicle, certain ideas are taken into consideration to achieve the selected product characteristics. Solubility of the active ingredients in the vehicle should be limited. If not the vehicle will reduce the activity of microsponges before the application [9]. To avoid cosmetic problems; in the vehicle more than $10 \%$ to $12 \% \mathrm{w} / \mathrm{w}$ microsponges should not be included. For active microsponges polymer designs and payloads should be optimized for the required release rate for the given time. When preparing suitable vehicles for a given application, some ideas should be kept in mind to achieve the desired product characteristics [27].

To prevent cosmetic problems, the powder load should be sufficient (not more than 10-12\%) in the vehicle [28].

- The solubility of the active agent in the vehicle should be restricted; otherwise, the skin will actually reduce the polymer before it is applied to the skin.

- $\quad$ Polymer design and loading levels should be properly selected for the release of active agent during the given period.

\subsection{Characteristics of materials that are entrapped in Microsponges [2, 29, 30]}

- The materials should be erased in water or should be slightly soluble.

- The material must be not react with monomers and should maintain the viscosity of the mixture during preparation.

- In Monomar, the material should be fully Egyptian, as well as the miscible with small amounts of water, besides the immiscible solvent.

- The material should not break the spherical structure of the microsponges.

- Polymerization catalyst as well as in the conditions of polymerization, the material should remain constant.

- The active ingredient is trapped in microsponge then such products can be included in many products such as cream, gels, powder, lotions and soap.

- To avoid cosmetic problems, the solubility of activators in the vehicle should be limited; in the vehicle more than $10 \%$ to $12 \% \mathrm{w} / \mathrm{w}$ microsponges should not be included. Otherwise the vehicle will reduce microsponges before the application. 
- Microsponges payloads and polymer designs should be optimized for the required release rate for the given period.

\subsection{Safety considerations}

Microsponge systems are made of famous used polymers with very low amounts of outstanding monomers, in addition, the high degree of cross-linking biologically disables them, as the body cannot biodegrade to reproduce them in other substances [31]. Animal statistics show that, after injection into the skin, MDS does not respond to any swelling by the body in response to its presence. Due to their size, these microspheres are very large, which pass through the stratum corneum. They are staying behind the surface of the skin, gradually releasing their material over time. This release pattern prevents excessive accumulation of active agents in epidermis and as a result, can increase the safety of topical drugs [32].

\subsection{Method of Microsponges preparation}

In the microsponges the drug loading can be done in two ways with one or two-stage process; for loading on the basis of physical-chemical properties of the drug [33]. If the drug is usually an inactive non-polar material, then it makes the porous structure fashionable, which is called porogen. Porogen drug, which neither interrupts polymerization nor activates it and stable for free radicals is entrapped with one-step process $[9,34]$.

\subsection{Liquid-liquid suspension polymerization}

The liquid-liquid suspension polymerization method is easily method for preparation of microsponges (one-step process). Polymerization done in the round bottom flask of styrene or methyl methacrylate. In their preparation, Nonpolar active ingredients are dissolved with monomer in a suitable solvent immediately possible and then dispersed in aqueous phase this includes additives such as surfactant, suspended agents, etc. assistance in the formation of suspension. Once identified with the different droplets of the desired size after the suspension, polymerization is activated by monomer stimulant or increased temperature or radiation [35].

The various steps of microsponges preparation are summarized as follows: [36].

- Monomer selection or monomer combination.

- Monomer chain formation as polymerization begins.

- Ladders formations as a result of cross linking between chain monomers.

- Monomer ladder folding to form spherical particles.

- Microspheres agglomeration, which give rise to formation of bunches of microspheres.
- Microspheres bunch binding to form microsponges. [37].

In some cases, an inactive liquid with water is invisible, but it is used to create pore network during the completely erosable environment with monomers. After the conclusion of polymerization, the fluid is released to the porous microspheres, that is, the microsponge. Regression within the preformed microsponges, then include functional substances [25].

Advantages: For drug loading one-step or two-step methods can be modified appropriately.

Disadvantages: Possible trapping of unreacted monomers and solvent traces, monomers require long time to react to non-uniform structure; requires two-step methods for thermodynamic sensitive drugs require less drug-loading capability.

\subsubsection{Quasi-emulsion solvent diffusion}

In quasi-emulsion solvent diffusion method (two steps process), of microsponges formulation an internal phase is used containing polymer such as eudragit RS100, which is dissolved in ethyl alcohol and external phase include polyvinyl alcohol and distilled water [38].

Different steps have been summarized in the preparation of microsponges by quasi-emulsion solvent diffusion method: [24].

- $\quad$ The internal phase which containing polymer such as eudragit RS 100 dissolved in ethyl alcohol.

- $\quad$ The drug is gradually added to internal phase (polymer solution) then dissolved under ultrasonication at $35^{\circ} \mathrm{C}$ and added plasticizer such as triethylcitrate (TEC) in order to aid the plasticity.

- The external phase which containing polyvinyl alcohol dissolved in distilled water.

- The internal phase is then poured into external phase (polyvinyl alcohol and distilled water) with continuous stirring for 2 hours.

- Then, separate the microsponges after mixture filtered.

- $\quad$ The microsponges washed and dried in an air heated oven at $40^{\circ} \mathrm{C}$ for $12 \mathrm{hr}$ [37].

Advantages: No monomer entrapment, Low solvent traces, High drug loading, No exposure of drug to ambient condition, Size of microsponges can be easily controlled by controlling the stirring, Spherical particles.

Disadvantages: Probable entrapment of unreacted monomers and solvent traces, Non uniform structure, requires a long time for the reaction of monomers, requires two-step method for thermo sensitive drugs that has low drug-loading efficiency. 
Table 4: Characterization parameters of microsponges:

\begin{tabular}{|c|c|c|}
\hline $\begin{array}{l}\text { Characterization } \\
\text { parameter }\end{array}$ & Methods & Remarks \\
\hline $\begin{array}{l}\text { Particle size } \\
\text { determination of } \\
\text { microsponges }\end{array}$ & $\begin{array}{l}\text { Microscopy diffractometry method used for Particle size } \\
\text { analysis of loaded and unloaded microsponges. To study } \\
\text { the effect of particle size on drug release, cumulative } \\
\text { percentage drugs should be issued from time to time with } \\
\text { various particle size microsponges. }\end{array}$ & $\begin{array}{l}\text { For all formulations, the value of } 50 \% \\
\text { size can be used as the mean size range } \\
{[20] .}\end{array}$ \\
\hline $\begin{array}{l}\text { Morphology of } \\
\text { microsponges }\end{array}$ & $\begin{array}{l}\text { Internal and external morphology can be studied by } \\
\text { scanning electron microscopy (SEM). }\end{array}$ & $\begin{array}{l}\text { The prepared microsponges are coated } \\
\text { with gold-palladium under the argon } \\
\text { atmosphere at room temperature and } \\
\text { then studied [39]. }\end{array}$ \\
\hline $\begin{array}{l}\text { Production yield of } \\
\text { microsponges }\end{array}$ & $\begin{array}{l}\text { Production yield of micro particle can certainly be } \\
\text { achieved by calculating the initial weight of raw material } \\
\text { and can be done based on the final weight of the } \\
\text { microsponges obtained. }\end{array}$ & $\begin{array}{l}\text { Production yield }=[\text { Practical mass of } \\
\text { microsponges } / \text { Theoretical mass } \\
(\text { polymer }+ \text { drug })] \times 100[40]\end{array}$ \\
\hline $\begin{array}{l}\text { Entrapment efficiency } \\
\text { of microsponges }\end{array}$ & $\begin{array}{l}\text { Loading efficiency of drug } \\
\text { determine by Drug extraction } \\
\text { Method. }\end{array}$ & $\begin{array}{l}\text { Entrapment efficiency }(\%)= \\
\text { [Actual drug content/Theoretical } \\
\text { Drug content] } \times 100[41] .\end{array}$ \\
\hline $\begin{array}{l}\text { Pore structure of } \\
\text { microsponges }\end{array}$ & $\begin{array}{l}\text { For controlling the power and duration of the } \\
\text { effectiveness of the active ingredient the pore volume and } \\
\text { diameter are important. The pore diameter affects the } \\
\text { active component of the micro-sponge in the vehicle in } \\
\text { which the material is dispersed. Mercury intrusion can be } \\
\text { employed to study the effect of pore diameter and } \\
\text { quantity with drug release rate from porosimetry } \\
\text { microsponges. }\end{array}$ & $\begin{array}{l}\text { Pore structure is determined by } \\
\text { Using Washburn [42]. }\end{array}$ \\
\hline $\begin{array}{l}\text { Resiliency of } \\
\text { microsponges }\end{array}$ & $\begin{array}{l}\text { According to the requirements of the final formulation, } \\
\text { the flexibility of microsponges can be modified to produce } \\
\text { soft or firmer beadlets. The rise in cross-linking reduces } \\
\text { the rate of release. }\end{array}$ & $\begin{array}{l}\text { No optimized method has been } \\
\text { developed to determine the } \\
\text { Resiliency of the micro particles [43]. }\end{array}$ \\
\hline $\begin{array}{l}\text { Drug content of } \\
\text { microsponges }\end{array}$ & $\begin{array}{l}\text { Drug content in microsponges } \\
\text { determine by Drug extraction } \\
\text { Method. }\end{array}$ & $\begin{array}{l}\text { These carriers have better drug } \\
\text { loading, thus they provide better drug } \\
\text { content [44]. }\end{array}$ \\
\hline $\begin{array}{l}\text { Drug release study of } \\
\text { microsponges }\end{array}$ & $\begin{array}{l}\text { Drug release study in microsponges determine by USP } \\
\text { apparatus II. }\end{array}$ & $\begin{array}{l}\text { When studied for oral use, the rotation } \\
\text { speed is } 100 \mathrm{rpm} \text {; Temperature is } \\
\text { maintained at } 37 \pm 0.5^{\circ} \mathrm{C} \text { on various } \\
\text { physical pH for a fixed time period [45]. }\end{array}$ \\
\hline
\end{tabular}

\subsection{Applications of microsponges system}

Microsponges are mostly used for topical delivery and are used for oral and simultaneous biopharmaceutical delivery. Many patents have reported that due to its high loading capacity and continuous release capacity it can be used as an excipient. This formulation offers many options for developing pharmaceutical and cosmetic products [12]. Microsponges are deliberately able to give a drug active ingredient in a minimal amount efficiently and increase stability, reduce side effects, and modify drug releases. Overthe-counter products that include the micro-sponge drug delivery system include many moisturizers, special renaissance products and sunscreens [25].

\subsubsection{Microsponge for topical delivery}

The purpose of topical formulations is to provide drug to the outer layers of the skin. Conventional topical formulations producing an extremely concentrated layer of active ingredient in skin that is speedily absorbed [12]. However, microsponge systems are deliberately able to efficiently deliver a drug active ingredient on a minimum dose. They consist of non-organized structures with porous surfaces through which active content is released in a controlled manner. Therefore, such systems can avert unwarranted accumulation of active ingredients within the epidermis and the dermis, thus they can show that reducing irritation and side effects due to drugs without reducing their efficacy decreases [13]. In addition to improving drug release and side effects, microsponges is also capable of increasing the stability of many drugs. The drug loaded porous microsponges can be further is incorporated into cream, lotions or powder. Microsponges are used for the topical delivery of many drugs and cosmetic agents [15]. In product or market placements, product uses topical microsponges system in three primary ways: [46, 24, and 47].

- As closed containers investment ingredients away from the skin for superficial action.

- As reservoirs releasing active ingredients over an extensive period of time.

- As receptacles for absorbing uninvited substances, such as more skin oils. 
Table 5: Microsponge formulation

\begin{tabular}{|l|l|}
\hline Drugs & Comments \\
\hline Dicyclomine & $\begin{array}{l}\text { Eudragit based microsponges were prepared by using a qusi-emulsion solvent diffusion method, } \\
\text { filled with Dicyclomine. The cumulative release for microsponges for more than 8 hours ranged } \\
\text { from 59 to 86\%. }\end{array}$ \\
\hline Flurbiprofen & $\begin{array}{l}\text { Microsponge system containing flurbiprofen was formulated for the colonic delivery of the drug for } \\
\text { targeted action [26]. }\end{array}$ \\
\hline Benzylperoxide & $\begin{array}{l}\text { BPO loaded Ethyl cellulose MDS was prepared which was capable to release of BPO into the skin. } \\
\text { And it has been shown that the BPO can reduce the effect of controlled release on the skin from the } \\
\text { delivery system, while percutaneous absorption can be reduced. }\end{array}$ \\
\hline Fluocinolone acetonide & $\begin{array}{l}\text { FA entrapped micro porous micro particles (microsponges) were formulated to control the release } \\
\text { of drug to the skin, which reduces the skin irritation and produce controlled release of active } \\
\text { medicament [26.] }\end{array}$ \\
\hline Hydroquinone (HQ) & $\begin{array}{l}\text { HQ 4\% with retinol 0.15\% entrapped in microsponge reservoirs was developed for the treatment of } \\
\text { melasma and PIH. Microsponges were used to release HQ gradually to prolong exposure to } \\
\text { treatment and to minimize skin irritation [12]. }\end{array}$ \\
\hline Aceclofenac & $\begin{array}{l}\text { Aceclofenac loaded microsponge are prepared by using quasiemulsion solvent diffusion method. It } \\
\text { is incorporated in gel base and various parameters are studied. }\end{array}$ \\
\hline
\end{tabular}

\subsubsection{Microsponge Technology in Cosmetics}

An exciting application of microsponge technology can be found in oral cosmetics, such as as to sustain the release of volatile ingredients, thus increasing the duration of the 'fresh feel'. Microsponges of such volatile ingredients may be effortlessly incorporated in tooth pastes or mouthwashes [36]. Microsponges may be used in a variety of coloured cosmetic products such as rouge or lipsticks to make them long lasting by using colour entrapment in microsponge. As mentioned above, Microsponges helps in dismantling uniforms and improves covering power. Thus, the colorful cosmetics prepared with microsponges will be very elegant [48].

Marketed formulation using MDS include skin products that can absorb large amounts of excess of skin oil from the surface of the skin, while the skin looks beautiful on the surface. These products include condioners, skin cleansing, moisturizers, oil control lotions, razor, deodorant, lipsticks, powder, makeup, and eye shadow; Which provides many advantages, including improved chemical and physical stability, better available concentrations, controlled release of active ingredients, brief skin irritation and sensitization, and exclusive touch properties [49].

\subsubsection{Microsponge for oral delivery}

In oral applications, the MDS has been shown to increase the rate of solubilization of the system of poorly soluble drugs by trapping in such drugs in pores. Since this pore is very small, particles are influenced in drug and a significant increase in surface area thus increases the rate of many solubilizations [50]. It has been shown that the microsponges system enhances the solubilization of drugs, which are poorly soluble in trapping these drugs in these pores [51].

A microsponges system gives many benefits for oral drug delivery, such as:

- $\quad$ Protect active ingredients in a limited environment and provide oral controlled delivery in the lower part of the gastrointestinal tract (GIT).

- Microsponges systems raise the solubility of poorly soluble drug by trapping these drugs in these porous structures.

- $\quad$ Since the porous structure of the microsponge is very small in size, the trapping drugs are dense for the micro particles with high surface area, and as a result, the rate of solubilization improves.

- Maximize the amount of drugs that are absorbed, as long as the microsponges system moves through the intestine to increase significantly.

\subsubsection{Microsponges in biopharmaceuticals delivery}

MDS is employed for both in tissue engineering as well as the delivery of biopharmaceuticals. Collagen microsponges have been studied with biodegradable polymers, which act as a new bioengineered cardiovascular prosthesis. Tabata et $a l$. has been studied type l collagen can act as a reservoir of basic fibroblastic growth factor. Chain et al, the expansion of biodegradable porous scaffolding for tissue engineering has also been studied [52]. 
Table 5: List of some marketed products of microsponge drug delivery system

\begin{tabular}{|c|c|c|}
\hline Product & Name Manufacturer & Advantages \\
\hline Carac Cream & $\begin{array}{l}\text { Dermik Laboratories, } \\
\text { Inc. Berwyn, PA } \\
19312 \text { USA }\end{array}$ & $\begin{array}{l}\text { Carac creams contain } 0.5 \% \text { fl luorouracil; Patented porous microsphere } \\
\text { with } 0.35 \% \text { was included in the methyl methacrylate / glycol dimethacrylate } \\
\text { cross polymers and dimethicon. Factors are the topical prescription product } \\
\text { for treatment of actinic keratosis (AK), which is due to the condition of } \\
\text { normal pre-cancerous skin, due to which the sun is caused by instability } \\
\text { [26]. }\end{array}$ \\
\hline Retin-A-Micro & $\begin{array}{l}\text { Ortho-McNeil } \\
\text { Pharmaceutical, Inc. }\end{array}$ & $\begin{array}{l}\text { In a retin-A-Micro } 0.1 \% \text { and } 0.04 \% \text { tretinoin, a patent was trapped in porous } \\
\text { microsphere, which included active ingredient in aqueous gel, methyl } \\
\text { methacrylate / glycol dimethacrylate cross-polymer to include traitinoin. } \\
\text { This formulation is used for topical treatment of acne vulgaris [21]. }\end{array}$ \\
\hline $\begin{array}{l}\text { Salicylic Peel } 20 \& \\
30\end{array}$ & Biophora & $\begin{array}{l}\text { Salicylic acid } 20 \% \text {, Micro-sponge technology has excellent exemption and is } \\
\text { used for skin resistant to more resistant skin types. It will appreciably } \\
\text { recover pigmentation, fine lines and acne concerns. Salicylic acid runs } \\
\text { effortlessly throughout Pierce, while reducing inflammation they are taken } \\
\text { out. This treatment effectively protects acne from the amazingly smooth and } \\
\text { clear skin texture [11]. }\end{array}$ \\
\hline $\begin{array}{l}\text { Line Eliminator Dual } \\
\text { Retinol Facial } \\
\text { Treatment. }\end{array}$ & Avon & $\begin{array}{l}\text { Two-system wrinkle action, both immediate and timely released. Obviously, } \\
\text { fine lines, wrinkles, and skin color seem to be related to aging [26]. }\end{array}$ \\
\hline $\begin{array}{l}\text { Micro Peel Plus /Acne } \\
\text { Peel }\end{array}$ & Biomedic & $\begin{array}{l}\text { The MicroPeel @ Plus procedure stimulate cell turn in excess of from first to } \\
\text { last the application of salicylic acid in the form of microcrystals using MDS. } \\
\text { Micro peel Plus forcefully releases the skin of all dead cells by defeat other } \\
\text { surface chemical peels, while not harming the skin [21]. }\end{array}$ \\
\hline $\begin{array}{l}\text { Retinol cream, Retinol } \\
15 \text { Night cream }\end{array}$ & Biomedic, Sothys & $\begin{array}{l}\text { A night-time treatment cream with microsponge technology using pure } \\
\text { static, a stable formula of vitamin A. Continuous use of retinol } 15 \text { will result } \\
\text { in fine lines and wrinkles, a noticeable improvement in the skin } \\
\text { discolorations due to aging, and enhanced skin smoothness [26]. }\end{array}$ \\
\hline $\begin{array}{l}\text { Lactrex }^{\mathrm{TM}} 12 \% \\
\text { Moisturizing Cream } \\
\text { (Pentewar RS et al., } \\
\text { 2014). }\end{array}$ & $\begin{array}{l}\text { SDR Pharmaceuticals, } \\
\text { Inc., Andover, } \mathrm{NJ} \text {, } \\
\text { U.S.A. } 07821\end{array}$ & $\begin{array}{l}\text { Microsponge }{ }^{\circledR} \text { technology has been included for effortless application and } \\
\text { for long lasting moisturization. Lactrex }{ }^{\mathrm{TM}} \text { includes water and glycerin, a } \\
\text { natural humectants help moisturize soft and dry, flaky, broken skin [52]. }\end{array}$ \\
\hline EpiQuin Micro & SkinMedica Inc & $\begin{array}{l}\text { Microsponges continuously release these ingredients in the skin throughout } \\
\text { the day. It provides skin with constant contact of hydroquinone and retinol } \\
\text { over time, thereby reducing skin irritation. EpiQuin Micro A Recipe } \\
\text { Moisturizing Fading Cream That Reduces Effect. These conditions are } \\
\text { known as melasma, after inflammatory hyper pagmentation or solar } \\
\text { lactagens. Also help in age spots, sun spots and facial discoloration [18]. }\end{array}$ \\
\hline $\begin{array}{l}\text { Oil free matte block } \\
\text { spf } 20\end{array}$ & Dermalogica & $\begin{array}{l}\text { This imperceptible oil-free sunscreen shields the skin from damaging UV } \\
\text { sun rays while controlling oil production, giving a healthy matte finish. } \\
\text { Designed with micro-sponge technology, the oil-free matte block absorbs oil } \\
\text { and can prevent brightness without any powder residues [32] }\end{array}$ \\
\hline $\begin{array}{l}\text { Sportscream RS and } \\
\text { XS }\end{array}$ & $\begin{array}{l}\text { Embil Pharmaceutical } \\
\text { Co. } \\
\text { Ltd. }\end{array}$ & $\begin{array}{l}\text { For the management of musculoskeletal conditions, timely analgesic anti- } \\
\text { inflammatory and counter-hibernation activated in a Microscope delivery } \\
\text { system (MDS) [53]. }\end{array}$ \\
\hline Oil Control Lotion & Fountain Cosmetics & $\begin{array}{l}\text { With feature-load lotion prepared with oil-absorbing micro-sponge } \\
\text { technology, eliminate the shine for hours. Complex shoulder swelling and } \\
\text { stiffness to promote antibiotic skin retention therapy naturally Acne-prone, } \\
\text { oily skin condition [40]. }\end{array}$ \\
\hline Ultra Guard & Scott Paper compony & $\begin{array}{l}\text { Microsponges system, which includes dimethicone to help protect a child's } \\
\text { skin with diaper rash. The new wipes contain a skin protector that helps } \\
\text { keep moisture and trouble from the skin of the baby. The solution is free of } \\
\text { alcohol, is hypoallergenic and contains dimethicone, a component found in } \\
\text { baby cream, lotions and skin protector [41]. }\end{array}$ \\
\hline Aramis fragrances & Aramis Inc. & $\begin{array}{l}\text { Microsponge formulation are available in the form of ultra-light powder, it } \\
\text { can easily take the aroma oil because of its suitable size. While the free-wide } \\
\text { powder maintains the feature where the release is controlled due to } \\
\text { moisture and temperature [52]. }\end{array}$ \\
\hline
\end{tabular}


Table 6: PATENT INFORMATION

\begin{tabular}{|l|l|l|}
\hline September 1, 1987 & $\begin{array}{l}\text { Won R of Advanced } \\
\text { Polymer Systems, Inc. }\end{array}$ & $\begin{array}{l}\text { Received (US Patent 4,690,825) for Developing method to deliver an } \\
\text { active ingredient by controlled time release using a novel delivery } \\
\text { vehicle that can be prepared by a process utilizing the active ingredient } \\
\text { as a porogen [53] }\end{array}$ \\
\hline September 8, 1992, & $\begin{array}{l}\text { Won R of Advanced Polymer } \\
\text { Systems, In }\end{array}$ & $\begin{array}{l}\text { Received (US Patent 5,145,675) for developing a two-step method for } \\
\text { the preparation of controlled release formulation [53]. }\end{array}$ \\
\hline July 23, 2006 & $\begin{array}{l}\text { Advanced Polymer Systems, } \\
\text { Inc. and subsidiaries ("APS" } \\
\text { or the "Company") }\end{array}$ & $\begin{array}{l}\text { Use MDS and related proprietary technologies to increase the } \\
\text { effectiveness of security, beauty and topical prescriptions on personal } \\
\text { care products such as counter ("OTC") and vitamin-A, traitinos and 5- } \\
\text { fluoraurus. . }\end{array}$ \\
\hline
\end{tabular}

Dean JR et al, US Patent Number Received 4863856 There are highly cross-linked collagen metrics for the development of weighted collagen microsponges, which is intended for use in fusion organisms in the reactor system. The pore structure of the surface of microsponges is an open dose for the size and size of the pore, which is suitable for stabilizing a range of bio active material.

\section{CONCLUSIONS}

The Microsponges Drug Delivery System is a novel strategy that regulates the delivery rate of active agents with less skin irritation and continues the drug during extended periods of time. They are stable over a wide range of $\mathrm{pH}(1-11)$ and temperature (up to $130^{\circ} \mathrm{C}$ ), and are compatible with most vehicles and materials. Because the average pore diameter is less than $0.25 \mathrm{pm}$, bacteria cannot penetrate these structures and reach their contents; Therefore, they are self-sterilizing and do not need any preservatives. Topical MDS can be used to prevent drug penetration into the subcutaneous layer and reduce skin irritancy. In doing so, this system can provide maximum effectiveness for therapeutic active agents, reducing their irritability and increasing their safety, increase product stability in a skilled and novel way. Apart from this, MDS can also be cost effective for the use of cosmetic and MDS offering high drug loading efficiency compared to other conventional dosage forms. Thus microsponge approach can be successfully utilized to improve the pharmacokinetics and therapeutic efficacy, simultaneously reducing irritability and toxicity of various highly potent drugs.

\section{Acknowledgement}

This review was supported by Chameli Devi group of institute Indore, We thank our colleagues who provided insight and expertise. We would also like to show our gratitude to the principal sir Dr. Arun kumar Gupta for sharing their pearls of wisdom with us, and I am also immensely grateful to Ram raj Choudhary for their contribution.

Abbreviations: MDS- microsponge drug delivery system, BPO- benzoyl peroxide

\section{REFERENCES}

1. Aloorkar N H, Kulkarni A S, Ingale D J, Patil R A, Micro Sponges as Innovative Drug Delivery Systems, International Journal of Pharmaceutical Sciences and Nanotechnology, 2012, 5(1), 1597-1606.

2. Saboji J, Manvi F, Gadad A and Patel B, Formulation and evaluation of ketoconazole microsponge gel by quassi emulsion solvent diffusion., J Cell Tissue Res., 2011; 11(1):2691-6

3. Chowdary K P R, Srinivasa Rao Y., Mucoadhesive microspheres for controlled drug delivery, Biol Pharmaceut Bull. 2004; 27(11):1717-24.
4. Sevgi F, Yurdasiper A, Kaynarsoy B, Turunç E, Güneri T and Yalçın A, Studies on mefenamic acid microparticles: formulation, in vitro release, and in situ studies in rats, AAPS PharmSciTech. 2009; 10(1):104-12.

5. Hu S-H, Liu T-Y, Liu D-M, Chen S-Y, Nano-ferrosponges for controlled drug release, J Control Rel. 2007;121(3):181-9.

6. Orlu M, Cevher E, Araman A, Design and evaluation of colon specific drug delivery system containing flurbiprofen microsponges, Int J Pharmaceut. 2006 Aug 2; 318(1-2):10317.

7. Devrim B, Canefe K., Preparation and evaluation of modified release ibuprofen microspheres with acrylic polymers (eudragit) by quasi emulsion solvent diffusion method: effect of variables, Acta Poloniae Pharm Drug Res. 2006; 63:52134.

8. Hong Y, Gao C, Shi Y and Shen J, Preparation of porous polylactide microspheres by emulsion-solvent evaporation based on solution induced phase separation. Polymer Adv Technol. 2005; 16(8):622-7.

9. Chandramouli Y, Shaik Firoz B, Yasmeen R, Vikram A, Mahitha $B$ and Aruna U. Microsponges: A Novel Drug Delivery System For Controlled Delivery Of Topical Drugs, ijpra, 2012-, 2(2), 79-86.

10. Kumari A, Hurkat P,Verma A,Jain SK, Microsponges: A Pioneering Tool for Biomedical Applications, Critical Reviews $^{\text {TM }}$ in Therapeutic Drug Carrier Systems, , 2016, Volume 33.

11. Patel E K, Oswal R J, “Nanosponge and Micro Sponges: A Novel Drug Delivery System", International Journal of Research in Pharmacy And Chemistry, 2012, 2(2), 237-244.

12. Kaity S, Maiti S, Ghosh A Pal K, D, Ghosh A and Banerjee S, Microsponges: a novel strategy for drug delivery system, J Adv Pharm Technol Res. 2010 Jul; 1(3):283-90.

13. Nacht S, Katz. The microsponge: a novel topical programmable delivery system. In: Osborne DW AA, editor, Topical drug delivery formulations, New York: Marcel Dekker; 1990, 299325.

14. Embil K and Nacht S. The Microsponge Delivery System (MDS): a topical delivery system with reduced irritancy incorporating multiple triggering mechanisms for the release of actives. J Microencapsul. 1996 Sep-Oct;13(5):575 88

15. Barkai A, Pathak Y, Benita S. Polyacrylate (Eudragit retard) microspheres for oral controlled release of nifedipine. I. Formulation design and process optimization, Drug Devel Indust Pharm. 1990; 16(13):2057-75.

16. Solanki D, Patidar S, Kag N, Motiwale M, Kushwah L and Mewade A, An Overview of Microsponge as a Novel Tool in Drug Delivery, Ijppr.Human, 2017; Vol. 9 (2): 64-77.

17. Mohite P B, Khanage S G, Harishchandre V S, Shirsath Y, Recent Advances In Microsponges Drug Delivery System, J Crit Rev, Vol 3, Issue 1, 9-16, 2016.

18. Manisha K T, Pawar A.Y, Microsponges: A Novel Strategy for Drug Delivery, International Journal of Pure \& Applied Bioscience, 2015, 3 (1), 224-235.

19. Verma N K, Panda P, Mishra J N, Vishwakarma D K, Gulzar A and Singh A P, Microsponges: An Approach to Novel Drug Delivery System-A Review, International Journal of Chemistry and Pharmaceutical Sciences, 2015, 3(5), 1719-1725.

20. Hussain H, Juyal D, Dhyani A, Microsponges: An Overview, International Journal of Drug Delivery Technology, 2014, 4(4), 58-66. 
21. D Kapoor, R B Vyas, C Lad, M Patel and B L Tyagi, A Review On Microsponge Drug Delivery System, Journal of Drug Delivery and Therapeutics, 2014, 4(5), 29-35.

22. Gangadharappa H V, Gupta N V, Prasad M S, Shivakumar H G Current trends in microsponge drug delivery system. Curr Drug Deliv. 2013 Aug; 10(4):453-65

23. Souza J D', Masvekar R, Pattekari P, Pudi S, More H, Microspongic delivery of fluconazole for topical application. 1st Indo-Japanese International Conference on Advances in Pharmaceutical Research and Technology. Mumbai, India: Pharmaceutical Research and Technology. 2005:25-9.

24. Aritomi H, Yamasaki Y, Yamada K, Honda H, Koishi M, Development of sustained-release formulation of chlorpheniramine maleate using powder-coated microsponge prepared by dry impact blending method. Pharmaceuticals (Japanese). 1996; 56(1):49-56.

25. Amrutiya N, Bajaj A, Madan M, Development of microsponges for topical delivery of mupirocin. AAPS PharmSciTech. 2009; 10(2):402-9.

26. Patel G, Patel JK, Use of a Microsponge in Drug Delivery Systems Pharmaceutical processing, 2008, 158.

27. Saraf A, Dasani A, Prathan HK. Microsponge Drug Delivery System AsAn Innovation in Cosmetic World: A Review. Asian Journal of Pharmaceutical Education and Research, 2012; 2278-7496.

28. Kircik L H. The microsponge delivery system reduces facial oiliness and shine during acne therapy. J Drugs Dermatol. 2013 Nov; 12(11):1268-70.

29. Shaha, V,Jain H,Krishna J,Patel P, Microsponge drug delivery: A Review International Journal of research in pharmaceutical sciences,Vol-1, Issue-2, 2010212-218,

30. Berg R A, Dean R C, Maffia G J, Phillips P G, Runstadler P W, Silver F H. Weighted collagen microsponge for immobilizing bioactive materials. Google Patents; 1989

31. Pandit A P, Patel S A, V P Bhanushali, V S Kulkarni and V D. Kakad. Nebivolol-Loaded Microsponge Gel for Healing of Diabetic Wound, AAPS PharmSciTech June 2016.

32. Mantry S, Bagchi A, Das S, Microsponge As A Novel Strategy of Drug Delivery System, Universal Journal of Pharmaceutical Sciences and Research,2015, 1 (1), 32-38.

33. Patel G and Patel JK, Use of a Microsponge in Drug Delivery Systems. Pharmaceutical processing 2008; 158.

34. Jain V, Jain D, Singh R, Factors effecting the morphology of eudragit S-100 based microsponges bearing dicyclomine for colonic delivery. J Pharmaceut Sci. 2011; 100(4):1545-52.

35. Vyas L. K., Tapar K. K., Laddha B. H., Lahoti A. O. and Nema R. K. Formulation and development of anti-blemish preparation using microsponge technology, Journal of Chemical and Pharmaceutical Research,2010, 2(5):562-571.

36. Guyot M, and Fawaz, F, Microspheres- Preparation \& physical characteristics, Int J Pharmaceutics, 1998:175: 61-74.

37. Won R, Two step method for preparation of controlled release formulations. Google Patents; 1992.

38. Martin A., Swarbrick J. \& Cammarrata A., In: Physical Pharmacy-Physical Chemical Principles, Pharma-ceutical Sciences. $3^{\text {rd }}$ Ed., 1991, 527.
39. Dubey D, Malviya R, Sharma P K, Advancement in microsponge drug delivery system: preparation methods, patents and commercial utility. Recent Pat Drug Deliv Formul. 2014.

40. Jadhav N, Patel V, Mungekar,S Bhamare G, KarpeM and Kadams V. Microsponge Delivery System: An updated review, current status and future prospects. Journal of Scientific and Innovative Research, 2013, 2 (6), 1097-1110.

41. Ravi R, Senthil S K, Parthiban S, Microsponges Drug Delivery System: A Review, International Journal of Pharmacy Review \& Research, 2013, 3(1), 6-11.

42. Abdelmalak NS, Menshawe S F El, A new topical fluconazole microsponge loaded hydrogel: preparation and characterization, Int J Pharm Pharm Sci. 2012; 4(Suppl 1):460-8.

43. Deshmukh K, Poddar S S, Tyrosinase inhibitor-loaded microsponge drug delivery system: new approach for hyperpigmentation disorders, J Microencapsulation. 2012; 29(6):559-68.

44. Patil R S, Kemkar V U, Patil S S, Microsponge Drug Delivery System: A Novel Dosage Form, American Journal of Pharmatech Research, 2012, 2(4), 228-251.

45. Rizkalla C M Z , latif Aziz R, II Soliman, In vitro and in vivo evaluation of hydroxyzine hydrochloride microsponges for topical delivery, AAPS PharmSciTech. 2011; 12(3):989-1001.

46. Kydonieus A F, Berner B, Transdermal delivery of drugs, CRC Press: Boca Raton, FL, 1987.

47. Tansel C, Omoglu CT, Baykara T, The effects of pressure and direct compression on tabletting of microsponges, Int. J. Pharm., 242 (2002), pp. 191-195

48. Sareen $\mathrm{R}$, Nath $\mathrm{K}$, Jain $\mathrm{N}$, Dhar $\mathrm{K}$, Curcumin loaded microsponges for colon targeting in inflammatory bowel disease: fabrication, optimization, and in vitro and pharmacodynamic evaluation, BioMed Res Int. 2014;1-7.

49. Bothiraja C, Gholap A D, Shaikh K S, Pawar A P, Investigation of ethyl cellulose microsponge gel for topical delivery of eberconazole nitrate for fungal therapy. Therapeut Deliv. 2014; 5(7):781-94.

50. Comoglu T, Savaser A, Ozkan Y, Gonul N, Baykara T, Enhancement of ketoprofen bioavailability by formation of microsponge tablets, Die Pharmazie. 2007 Jan; 62(1):51-4.

51. Maiti S, Kaity S, Ray S, Sa B, Development and evaluation of xanthan gum-facilitated ethyl cellulose microsponges for controlled percutaneous delivery of diclofenac sodium, Acta pharmaceutica (Zagreb, Croatia), 2011, Sep 1;61(3):257-70.

52. Pentewar RS*, Sumaiya K, Rohit B, Pulgamwar G, MDS Technology: An Approach for Topical, Oral Controlled and Cosmetic Formulations, ISSN: 0975-8585,5(3) Page No. $1170,2014$.

53. Kumar J, Muralidharan S, Ramasamy S, Microsponges Enriched Gel (MEGs): A Novel Strategy for Ophthalmic Drug Delivery System Containing Ketotifen, Journal of Pharmaceutical Sciences and Research, 2013, 5(4), 97 - 102.

54. Dean, Jr. et al received US patent no. 4863856. 